\title{
Hypoglycaemic injury spares thalamus, spoils striatum and leaves only a rest tremor
}

\author{
Laura S Boylan
}

Department of Neurology, New York University School of Medicine, New York, USA

\section{Correspondence to} Dr Laura S Boylan, laura. boylan@nyumc.org

Accepted 25 August 2016
CrossMark

To cite: Boylan LS. BMJ Case Rep Published online: [please include Day Month Year] doi:10.1136/bcr-2016217245

\section{DESCRIPTION}

A patient was found unresponsive but breathing with blood glucose of $45 \mathrm{mg} / \mathrm{dL}$ following insulin overdose. On unsedated examination the following day the patient's eyes were roving with limbs flaccid. The best responsiveness was triple flexion withdrawal of the left leg to deep nail bed pressure. There was a continuous symmetric low amplitude 3-4 Hz pill-rolling type rest tremor of both hands.

To the best of the author's knowledge this is the first report of rest tremor in deep coma. There is one prior case, including video, of a similar tremor in a patient following brain death. ${ }^{1}$ As in the prior case, the tremor was short lived, lasting $<24$ hours.

Specific regional vulnerability is seen with hypoxia and various toxins such as organophosphates or manganese. Vulnerabilities may vary by metabolic demand, vascular supply, biochemical milieu or other factors. Hypoxic and hypoglycaemic injury preferentially affect the grey matter. However, hypoglycaemic injury is characterised by thalamic sparing. ${ }^{2}$ This was seen in the present patient (figure 1). Also notable is sparing of the pallidum, including the internal globus pallidus (GPi), a major output pathway for the basal ganglia.

While in this case selective pallidal sparing was associated with emergent rest tremor, selective pallidal damage may also be associated with emergent rest tremor (eg, manganese or carbon monoxide poisoning). In Parkinson's disease and essential tremor ablation or deep brain stimulation to the thalamus or GPi alleviates tremor. Despite extensive research, the circuitry involved in Parkinsonian rest tremor is poorly understood. ${ }^{3}$

\section{Learning points}

There are structurally specific vulnerabilities to generalised toxic/metabolic brain injury.

- Rest tremor can occur despite loss of all voluntary movement in deep coma.

\section{Competing interests None declared.}

Provenance and peer review Not commissioned; externally peer reviewed.

\section{REFERENCES}

1 Araullo ML, Frank JI, Goldenberg FD, et al. Transient bilateral finger tremor after brain death. Neurology 2007;68:E22.

2 Fujioka M, Okuchi K, Hiramatsu Kl, et al. Specific changes in human brain after hypoglycemic injury. Stroke 1997;28:584-7.

3 Helmich RC, Hallett M, Deuschl G, et al. Cerebral causes and consequences of parkinsonian resting tremor: a tale of two circuits? Brain 2012;135(Pt 11):3206-26.

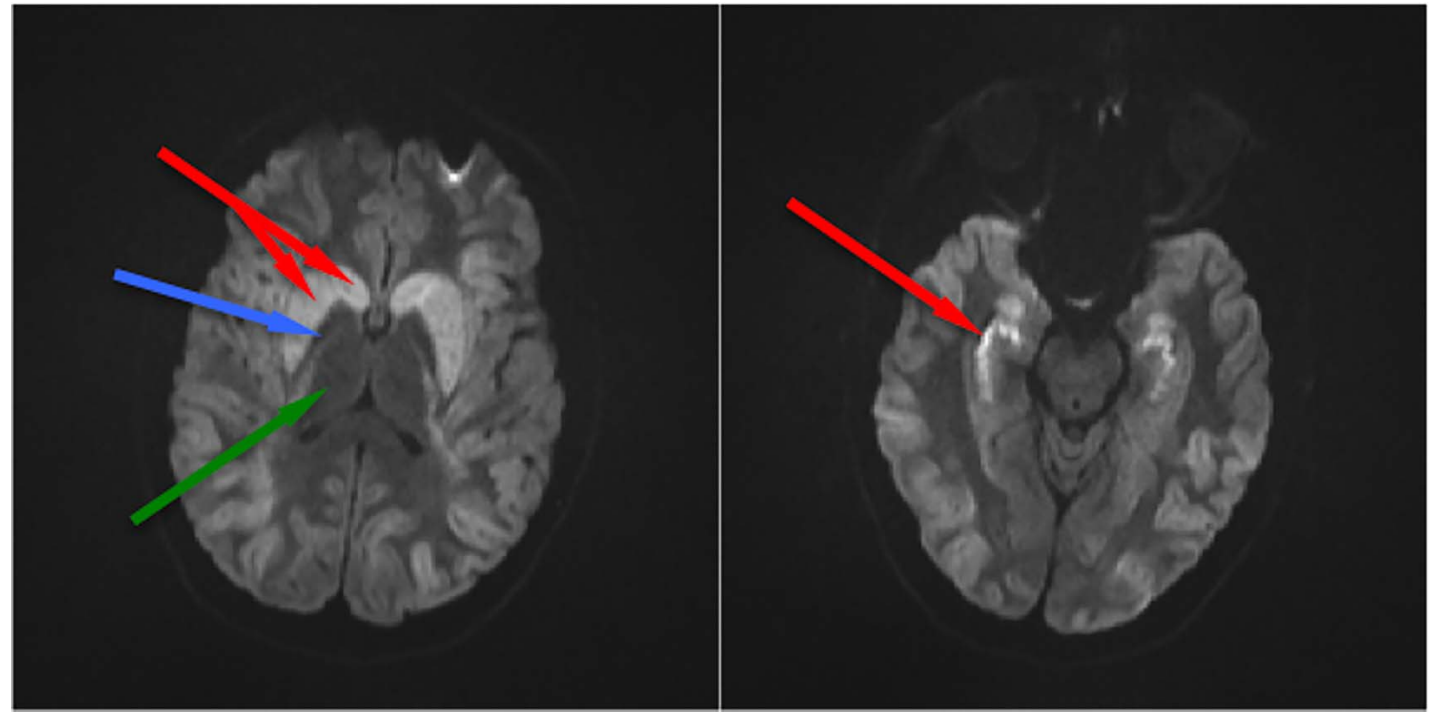

Figure 1 Diffusion-weighted MRI showing hyperintensity in the caudate and putamen of the striatum (left image, red arrows) and hippocampi (right image, red arrow) bilaterally following acute hypoglycaemia. The cortex is also diffusely, though less markedly, hyperintense. Cortex, deep grey matter (basal ganglia) and hippocampus are selectively vulnerable to hypoxic injury. Sparing of the thalamus (green arrow) has been reported as specific to hypoglycaemia. ${ }^{2}$ Note also the preservation of the pallidum (blue arrow) within the striatum in our patient. The internal globus pallidus is a major output pathway of the basal ganglia. 
Copyright 2016 BMJ Publishing Group. All rights reserved. For permission to reuse any of this content visit http://group.bmj.com/group/rights-licensing/permissions.

BMJ Case Report Fellows may re-use this article for personal use and teaching without any further permission.

Become a Fellow of BMJ Case Reports today and you can:

- Submit as many cases as you like

- Enjoy fast sympathetic peer review and rapid publication of accepted articles

- Access all the published articles

- Re-use any of the published material for personal use and teaching without further permission

For information on Institutional Fellowships contact consortiasales@bmjgroup.com

Visit casereports.bmj.com for more articles like this and to become a Fellow 